(c) 2008 Elsevier B.V. All rights reserved.

\title{
Rapid and sensitive detection of ostreid herpesvirus 1 in oyster samples by real-time PCR
}

\author{
J.F. Pepin ${ }^{a},{ }^{*}$, A. Riou ${ }^{a}$ and T. Renault ${ }^{a}$ \\ ${ }^{a}$ Institut Français de Recherche pour l'Exploitation de la Mer (IFREMER), Laboratoire de Génétique et Pathologie \\ (LGP), 17390 La Tremblade, France \\ *: Corresponding author : Pepin J. F., email address : ifpepin@ifremer.fr
}

\begin{abstract}
:
Herpes and herpes-like virus infections have been reported in various marine mollusc species associated with high mortality rates. Following the characterisation and genome sequencing of ostreid herpesvirus 1 (OsHV-1), specific diagnostic tools have been developed based on conventional PCR techniques or in situ hybridisation. We have now developed a real-time PCR assay for rapid, sensitive and quantitative detection of OsHV-1, and compared it with a conventional PCR technique described previously. The new assay utilised SYBR $®$ Green chemistry with specific primers C9/C10 targeting the $\mathrm{C}$ region. The melt curve analysis of OsHV-1 DNA or DNA extracted from infected material showed only one melting temperature peak $\left(75.75 \pm 0.1^{\circ} \mathrm{C}\right)$. The assay had a detection limit of $4 \mathrm{copies} / \mu \mathrm{L}$ of viral genomic DNA and a dynamic range of 5 logs. Using infected oyster samples as template, the assay was about 100 -fold more sensitive than single PCR method using C2/C6 primers. The assay was applied successfully for rapid diagnosis (100 min) and quantitation of OsHV-1 in different developmental stages of Crassostrea gigas. Although it already exists a competitive PCR method to quantify OsHV-1 DNA, quantitative data that will emerge in future using the new sensitive and reliable assay will illuminate aspects of pathogenesis, in particular the viral loads in asymptomatic oysters and the kinetics of infection in specific target tissues.
\end{abstract}

Keywords: Herpesvirus; Ostreid herpesvirus 1; Crassostrea gigas; Real-time PCR; SYBR ${ }^{\circledR}$ Green 


\section{Introduction}

Herpesviral infections are frequently reported (Renault and Novoa, 2004) and have been associated with high mortality rates in larvae and spat of $C$. gigas in different French locations (Nicolas et al., 1992; Renault et al., 1994b). The virus isolated from infected $C$. gigas larvae has been classified as a member of the Herpesviridae under the name Ostreid Herpesvirus 1 (OsHV-1) (Davison et al., 2005). OsHV-1 was the first herpesvirus to be identified in an invertebrate host, and is associated with massive mortality outbreaks in the Pacific oyster, Crassostrea gigas, and other bivalve species (Arzul et al., 2001a, 2001b).

The association of OsHV-1 to larval and spat mortalities among economically important shellfish species lead to the development of specific and sensitive diagnostic methods including PCR and in situ hybridization (ISH) (Renault and Lipart, 1998; Renault et al., 2000b; Arzul et al., 2002, Lipart and Renault, 2002, Bastista et al., 2005, Barbosa Solomieu et al., 2005).

Routinely, at the IFREMER's laboratory (La Tremblade, Charente Maritime France), viral detection was performed by conventional PCR, which is described as a technique of choice for detecting OsHV-1 both in larvae and in adults. However, according to the OIE International Aquatic Animal Health Code, OsHV-1 infection is not a notifiable disease and no diagnostic reference method or gold standard method are in force.

As no cell culture from marine molluscs is available, no reliable easy quantification of virus or DNA copies of OsHV-1 is routinely done or disposal. Nevertheless, an assay of quantification has been developped based on a competitive PCR method using an internal standard (Arzul et al., 2002, Renault et al., 2004). 
Very few data are known about the minimal number of virions to induce the disease (naturally or in experimental infection), neither the number DNA copies present in asymptomatic oysters (Arzul et al., 2002, Renault et al., 2004). Futhermore no or few data are available on pathogenesis, kinetic of viral replication. Moreover, conventional PCR technique is (i) based on the use of ethidium bromide a toxic compound, (ii) difficult for interpretation when bands in agarose are weak, and (iii) is not a direct quantitative data. Finally, PCR is more time consuming than real-time PCR and do not allow the scoped screening of numerous samples. We assume that this real-time PCR may be helpfull to carry out quantitative approaches and epidemiological studies. As long as OsHV-1 seems to be able to persist in its hosts, particularly in asymptomatic adults, adults oysters may play the role of healthy carriers and reservoirs of the virus. Gametes screening appears as a suited technique to control the viral disease and quantitative PCR is a useful technique. The development of a quantitative PCR using real-time PCR appeared to be needed (Barbosa et al., 2005, Renault et al., 2004).

The aim of the present study was to develop a real-time PCR diagnostic tool based on SYBR Green chemistry to detect and quantify OsHV-1 in $C$. gigas at different developmental stages.

\section{Materials and methods}

\subsection{Oyster samples}

All the samples were Pacific oysters C. gigas, from different French locations. This study was carried out on frozen infected or not infected samples of larvae (<day 30), spat (day 50), juvenile oysters (5 months) and adults (> one year) with or without mortality. 


\subsection{Sample preparation and DNA extraction}

According to different developemental stages, several DNA extraction protocols were performed. Larval samples and infected spat (day 50) were prepared as previously described (Renault et al. 2000b). Briefely, $50 \mathrm{mg}$ of frozen larvae were ground in $50 \mu \mathrm{l}$ double-distilled water with disposal piston pellet. Ground larval samples were denatured in a boiling water bath for $10 \mathrm{~min}$ and centrifuged at $1000 \times g$ for $5 \mathrm{~min}$. Supernatants were recovered and immediately diluted 10 -fold in double-distilled water and frozen at $-20^{\circ} \mathrm{C}$.

Juvenile and adult samples were prepared using the protocol describe above. However, tissues were initiallly diluted at $1: 6$ and clarified at $10000 \times g$ for 5 min. One hundred microliter of recovered supernatant were treated using a commercial DNA tissue kit according to the manufacturer protocol (QIAgen -Qiamp tissue mini kitß), (Robledo et al., 2000). Final DNA elution was performed wih $100 \mu \mathrm{L}$ of double-distilled. The extracted DNA was stored at $-20^{\circ} \mathrm{C}$ until use as template for PCR. DNA concentrations were measured as OD absorbance at $260 \mathrm{~nm}$.

\subsection{Quantitative control for OsHV-1 DNA standard curve}

In order to quantify viral DNA, a quantitative control was draw up. A dilution standard curve was made by using a stock solution of genomic OsHV-1 DNA extracted from purified particules (Le Deuff et Renault, 1999) previously titrated at $5 \times 10^{6}$ DNA copies/ $\mu \mathrm{L}$ using a competitive PCR (Renault et al., 2004). Five-fold serial dilutions were performed in distilled water. 


\subsection{Conventional PCR}

One round PCR assays were performed using a previously described protocol (Renault and Arzul, 2001) with two sets of primers: The primer pair $C_{2} / C_{6},\left(C_{2}: 5\right.$ '-CTC TTT ACC ATG AAG ATA CCC ACC-3' and ( $_{6}$ : 5'-GTG CAC GGC TTA CCA TTT TT-3') amplified a $710 \mathrm{bp}$ fragment. This primer pair was designed from a viral sequence named C being located in an inverted repeat region and present as two copies in the genome of OsHV-1 (Arzul et al. 2001). This viral sequence encodes two proteins of unknown functions. A competitive PCR method previously developed (Arzul et al. 2002, Renault et al. 2004) was also used to detect inhibition during PCR reactions with the primer pair $\mathrm{C}_{2} / \mathrm{C}_{6}$. In presence of the internal standard (a $77 \mathrm{bp}$ deleted amplicon), these primers amplify a DNA fragment of $634 \mathrm{bp}$. PCR products underwent electrophoresis on $1.5 \%$ agarose gels stained with ethidium bromide $(0.5 \mu \mathrm{g} \mathrm{mL}-1)$ and fragments size was controled using a size markers [100-1000pb], SF100, Eurogentec . Genomic OsHV-1 DNA extracted from purified particules (Le Deuff and Renault, 1999) constituted the positive control. Deionized water was used in negative controls.

\subsection{Real-time PCR}

Three sets of primers previously designed (Arzul, 2001) were assessed, targeting three different regions of viral DNA : B, C and Gp. B region encodes a putative apopotosis inhibitor and the Gp region encodes part of a putative glycoprotein (Arzul et al., 2001b, 2001c). $B_{4}\left(5^{\prime}\right.$ ACT GGG ATC CGA CTG ACA AC 3’)/ B ${ }_{3}$ ( 5' GTG GAG GTG GCT GTT GAA AT 3') yield a PCR product of $196 \mathrm{bp}, \mathrm{C}_{9}$ ( 5'- GAG GGA AAT TTG CGA GAG AA -

3')/ C $_{10}$ (5' ATC ACC GGC AGA CGT AGG 3') yield a PCR product of 207 bp, Gp $4\left(5^{\prime}\right.$ 
GGC GTG CAA ACT CGA TTA AA 3')/ Gp 7 (5' TTA CAC CTT TGC CGG TGA AT 3' ) yield a PCR product of $85 \mathrm{bp}$.

All amplification reactions were performed in a total volume of $25 \mu \mathrm{L}$ with an Mx3000p Thermocycler sequence detector (Stratagene) with 96 microwell plates.

Each well $(25 \mu \mathrm{L})$ contained $5 \mu \mathrm{L}$ of diluted extracted DNA product (sample) or $5 \mu \mathrm{L}$ of genomic OsHV-1 DNA (standard), $12.5 \mu \mathrm{L}$ of Brilliant ${ }^{\circledR}$ SYBR Green I PCR Master Mix or Fullvelocity® Master Mix (Stratagene), $2.5 \mu \mathrm{L}$ of each diluted primers $(2 \mu \mathrm{M})$ and $2.5 \mu \mathrm{L}$ distilled water. Reaction thermal conditions were : 1 cycle of preincubation at $95^{\circ} \mathrm{C}$ for 10 min (segment 1$) ; 40$ cycles of amplification at $95^{\circ} \mathrm{C}$ for $30 \mathrm{~s}(15 \mathrm{~s}$ with Fullvelocity master mix), $60^{\circ} \mathrm{C}$ for $45 \mathrm{~s}\left(30 \mathrm{~s} /\right.$ Fullvelocity master mix) and $72^{\circ} \mathrm{C}$ for $45 \mathrm{~s}$ with Brilliant master mix only (segment 2) ; melting temperature curve analysis at $95^{\circ} \mathrm{C}$ for $60 \mathrm{~s}, 60^{\circ} \mathrm{C}$ for $30 \mathrm{~s}$ and $95^{\circ} \mathrm{C}$ for $30 \mathrm{~s}$ (segment 3). Time for amplificati on step was 90 minutes and 70 minutes for Brilliant or Fullvelocity master mix runs, respectively. Time for melting curve step was 23 minutes for both. These two premix differ for the origin and properties of the DNA polymerase. In preliminary trials, we compared the Brilliant and the Fullvelocity premix on genomic OsHV-1 DNA dilutions. The Fullvelocity was as good as the Brilliant premix and gave one earlier CT signal than Brilliant, due to the specific hot start DNA polymerase. According to these data we the Fullvelocity premix was chosen for all following analyzis .

Amounts of viral DNA (copies/ $\mu \mathrm{L}$ or $\mathrm{mg}$ ) in each experiment were calculated by comparison with standard curve values obtained from amplification reactions carried out with serial dilutions of the genomic OsHV-1 DNA. The software provided with the real-time thermocycler (Mx3000p-Stratagene) permitted measurment calculation and analysis.

Real-time PCR analysis was performed in triplicate with $5 \mu \mathrm{L}$ of sample dilutions as DNA template or viral DNA control. Absolute quantitation for OsHV-1 DNA copies was carried 
out comparing the Ct (Cycle thershold value) obtained against the standard curve with known copy numbers.

Each run included a positive DNA control (genomic OsHV-1 DNA for absolute quantification), and blank controls (NTC, no template control : deionised sterile water). PCR efficiency was also calculated and corresponds to the proportion of template molecules that are doubled every cycle, PCR efficiency $=\left[10^{(-1 / \text { slope })}-1\right] \times 100$. PCR efficiency (E) was determined by drawing standard curves from a serial dilutions analysis of genomic OsHV-1 DNA to ensure that $\mathrm{E}$ ranged from $95 \%$ to $105 \%$ and coefficient of determination, Rsq >0.98. In order to allow detection of non-specific products a dissociation protocol (melt curve) took place after amplification cycles. SYBR green fluorescence generate by double stranded amplicon dissociation and associated temperature (Tm value) were recorded.

\subsection{Assay precision}

In order to determine the intra-assay variability of this SYBR Green PCR, we prepared separatly 3 ranges of standard with three dilutions of viral DNA. These samples were assayed in a same plate, within the same run.

Six different experiments were carried out at differents runs and days to assess the inter variability of this assay, using 4 viral DNA dilutions $\left(2 \times 10^{5}\right.$ copies ; $4 \times 10^{3}$ copies ; 8 x $10^{2}$ copies ; $2 \times 10^{2}$ copies $\left./ \mu \mathrm{L}\right)$.

For these parameters, the mean, standard deviation (S.D.) and coefficient of variation (CV) for each DNA dilution were calculated independently from three replicates values. 


\section{Results}

\subsection{Primer selection}

A preliminary test was carried out to select the most efficient set of primers with SYBR Green I chemistry PCR to detect and quantify OsHV-1 DNA. Primer pairs $\mathrm{C}_{9} / \mathrm{C}_{10}$, $G p_{4} / G p_{7}$ and $B_{3} / B_{4}$ have been tested using dilutions of genomic OsHV-1 DNA. The Q-PCR yielded specific amplification. A single peak was recorded on melt curves. Tm were $79.50^{\circ} \mathrm{C}, 7^{2} .27^{\circ} \mathrm{C}, 75.7^{\circ} \mathrm{C}$ for $\mathrm{B}{ }_{3} / \mathrm{B}_{4}, \mathrm{Gp}_{4} / \mathrm{Gp}_{7}$ and $\mathrm{C}_{9} / \mathrm{C}_{10}$ (Fig. 1 ) respectively. NTC of each primer pair presented no peak (primer dimers were not observed)

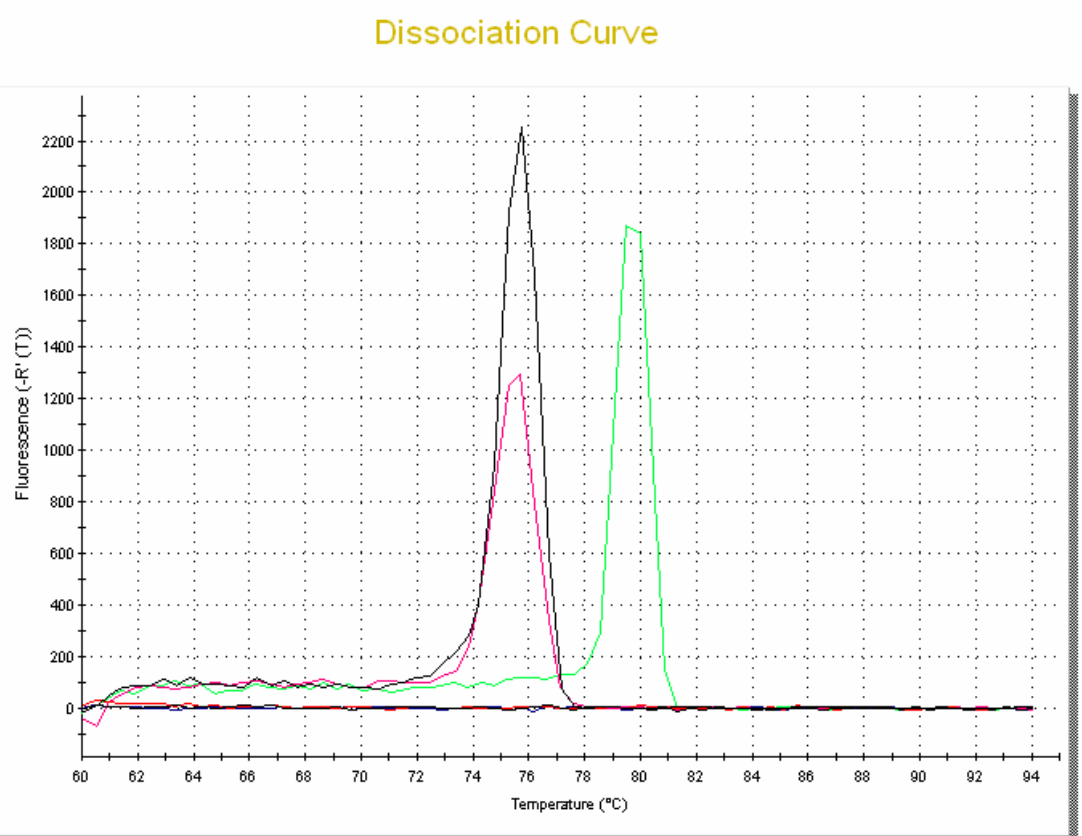

Fig. 1 . Melting curves of the amplified fragments generated by real-time PCR, using 3 primers pairs targeting 3 different regions of genomic OsHV-1 DNA. Base lines correspond to each NTC primer set. $B_{3} / B_{4}$ : green curves, $\mathrm{Gp}_{4} / \mathrm{Gp}_{7}$ : red curves, $\mathrm{C}_{9} / \mathrm{C}_{10}$ : black curves. 
$\mathrm{C}_{9} / \mathrm{C}_{10}$ primers yielded acceptable parameters for reliable Q-PCR with OsHV-1 DNA, as well as $G p_{4} / G p_{7}$ primers that have very close parameters, but quite less sensitivity ( $\geq 50$ copies $/ \mu L) . B_{3} / B_{4}$ primers have a lower efficiency $(81.3 \%)$ and a poor sensitivity ( $\geq 500$ copies $/ \mu \mathrm{L})$. The primer pair $\mathrm{C}_{9} / \mathrm{C}_{10}$ appeared the most relevant according to its good sensitivity and efficiency (Table1).

Then $C_{9} / C_{10}$ primer pair has been validated. $C_{9}$ and $C_{10}$ were used at a concentration 200 $\mathrm{nM}$ with $2.5 \mu \mathrm{L}$ in a $25 \mu \mathrm{L}$ final volume reaction $\left(50 \mathrm{nM}\right.$ of $\mathrm{MgCl}_{2}$, annealing extension temperature at $60^{\circ} \mathrm{C}$ ). According to these results $C_{9} / C_{10}$ primer pair was selected to develop the quantitative PCR.

Table 1

Data from three primers set valuation

$\begin{array}{ccccccc}\text { Primers } & \text { Ct at } 5 \times 10^{5} \text { DNA copies } & \mathrm{R}^{\mathrm{sq}} & \text { Slope } & \text { Efficiency }(\%) & \begin{array}{c}\text { Tm } \\ \text { Product }\end{array} & \text { Threshold } \\ \mathrm{B}_{3}-\mathrm{B}_{4} & 30,67 & 0,933 & -3,871 & 81,3 & 79,5 & 2342,913 \\ \mathrm{Gp}_{4}-\mathrm{Gp}_{7} & 18,48 & 0,997 & -3,364 & 98,3 & 75,27 & 140,536 \\ \mathrm{C}_{9}-\mathrm{C}_{10} & 18,24 & 1,00 & -3,297 & 101,1 & 75,75 & 543,717 \\ \mathrm{~B}_{3}-\mathrm{B}_{4} & \text { Standard curve }=\left(\mathrm{Y}=-3.871{ }^{*} \log (\mathrm{x})+52.73\right) & & & \\ \mathrm{Gp}_{4}-\mathrm{Gp}_{7} & \text { Standard curve }=\left(\mathrm{Y}=-3.36{ }^{*} \log (\mathrm{x})+37.83\right) & & & \\ \mathrm{C}_{9}-\mathrm{C}_{10} & \text { Standard curve }=\left(\mathrm{Y}=-3.297{ }^{*} \log (\mathrm{x})+36.95\right) & & & \end{array}$

\section{2 real-time PCR performance}

Assay specificity and sensitivity

\section{2. 1 Specificity :}

In order to determine the ability of the assay to only amplify DNA from OsHV-1, we systematically have monitored in each run and each replicate the Tm value of amplified 
products from the melt curve. Standard and positive samples results gave a specific peak at $75.75{ }^{\circ} \mathrm{C}+/-0.1^{\circ} \mathrm{C}$ (Fig. 2). If a sample produced non specific amplicons, it was considered as a negative sample. The negative controles (NTC) had CT values over 37 cycles, and no specific peak was obtained for NTC. We have controled the size of realtime PCR amplicons on agarose gel and bands were observed at the expected size (197pb), (Fig.3b, lanes 15-20).

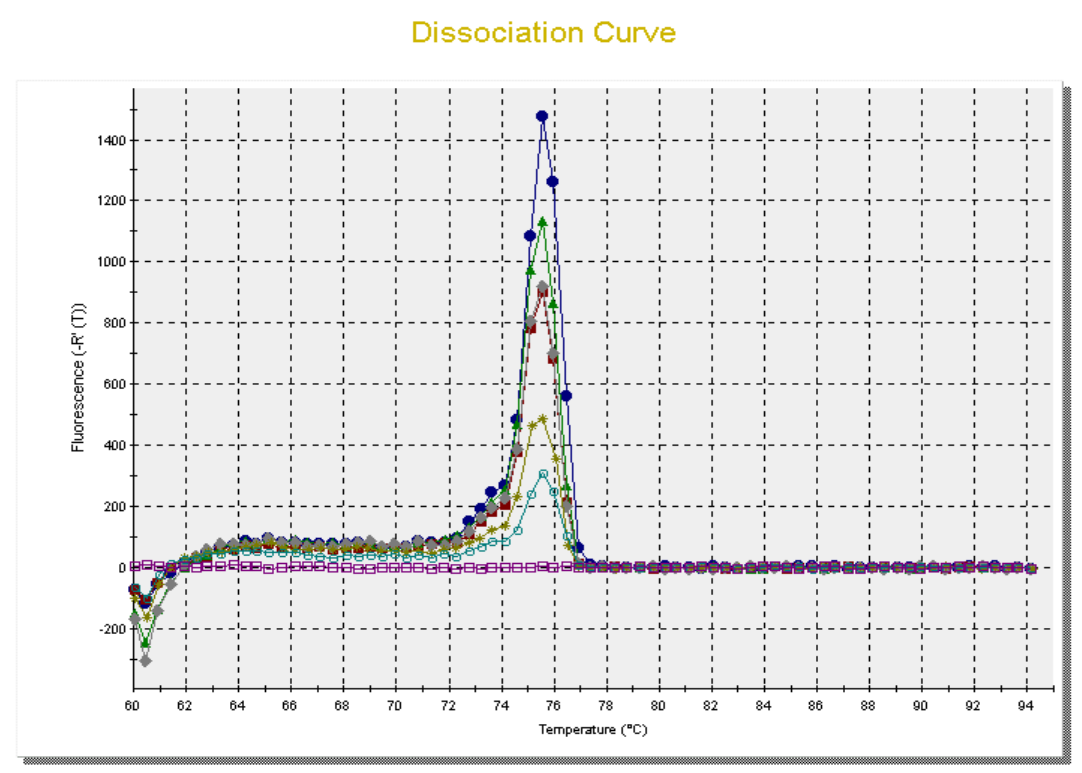

Fig. 2. SYBR Green specific dissociation curves of dilutions of genomic OsHV-1 DNA using $\mathrm{C}_{9} / \mathrm{C}_{10}$ primer pair $\left(\mathrm{Tm}=75.75 \mathrm{C}^{\circ}+/-0.1\right)$. Purple square $\mathrm{b}$ aseline plot corresponds to the NTC. The plot shown is based on the first derivative of the normalized fluorescence reading as a function of melting temperatures collected during thermal profile segment 3 .

\section{2. 2 Sensitivity :}

To determine sensitivity of SYBR Green PCR, serial dilutions of genomic viral DNA were prepared. A linear relationship was observed between the input copy number of the viral DNA template $(X)$ and the CT values associated $(Y)$, for over $5 \log _{10}$ dilutions. 
Whithin five different runs, the linear regression obtained for dilution series was $Y=-3.417$ $x \log (X)+41$, with a coefficient of determination, $R s q=0.999$ and an Efficiency of $96.2 \%$ (Fig. 3a).

The sensitivity was considered reliable to quantify systematically 4 copies $/ \mu \mathrm{L}$. Conventional PCR with $\mathrm{C}_{2} / \mathrm{C}_{6}$ primer set presented a sensitivity equivalent to $4 \mathrm{fg}$ of genomic viral DNA per reaction, wich correspond to $2 \times 10^{2}$ DNA copies/ $\mu \mathrm{L}$ (lane 4, Fig. 3b).

Fig. 3a. Linearity and sensitivity of SYBR Green PCR using $C_{9} / C_{10}$ and genomic viral DNA dilutions. Linear regression plots of SYBR Green assay with standard curve ( X : Log copy number ; Y : CT values, viral DNA dilutions : $5 \times 10^{3}$ copies ; $1 \times 10^{3}$ copies ; $2 \times 10^{2}$ copies ; $4 \times 10^{1}$ copies ; 8 copies ; 4 copies).

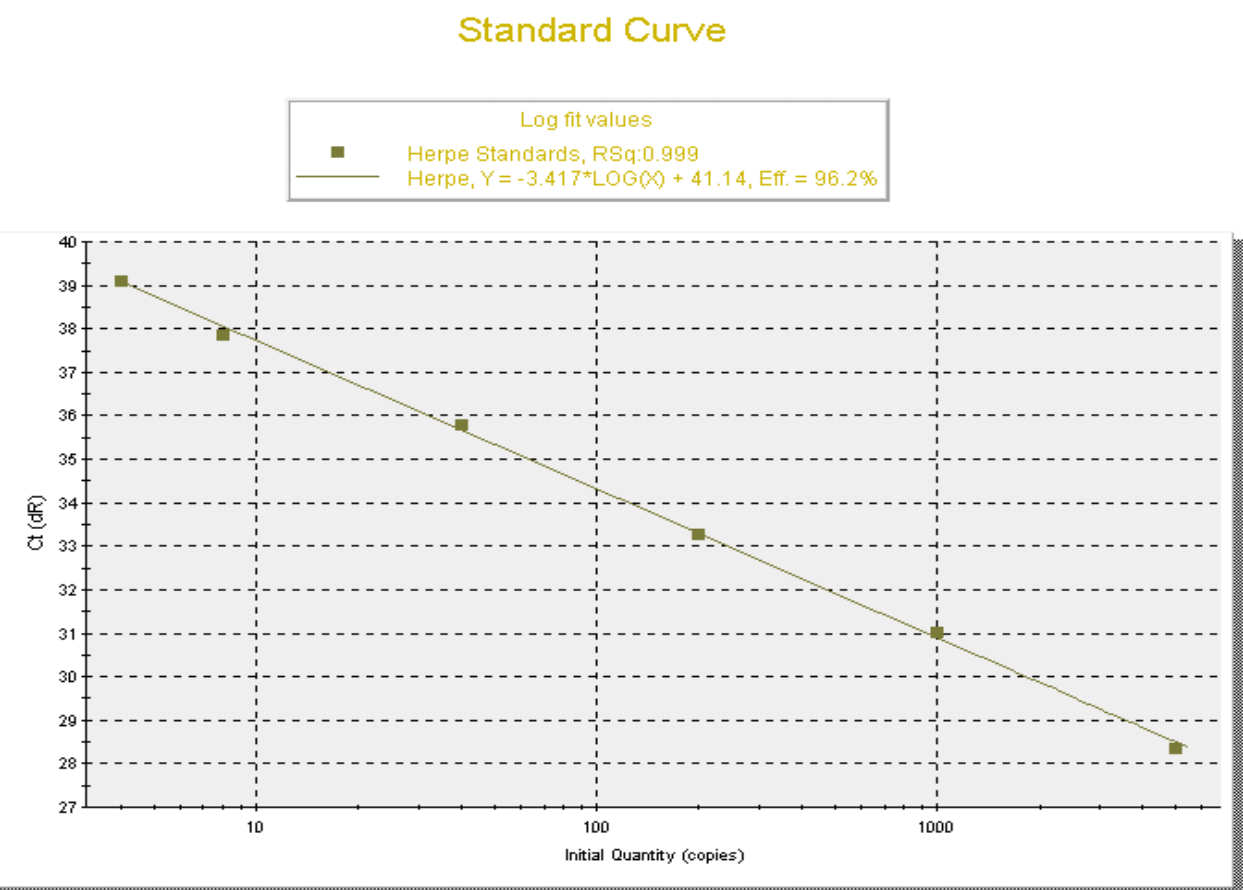


Fig. 3b. Sensitivity of viral DNA detection by conventional PCR using $C_{2} / C_{6}$ primer pair versus SYBR Green real-time PCR using $\mathrm{C}_{9} / \mathrm{C}_{10}$ primer pair. Lane 1: size markers (SF100,Eurogentec). Lanes 2-14: PCR products from conventional PCR, expected size $710 \mathrm{bp}$. Lanes 2-6: 5-fold serial dilutions of viral DNA from , $5 \times 10^{3}$ to 8 copies, lane 7: 2 copies. Lane 8: negative controle. Lanes 9-14: larvae and seed oyster samples $<50$ copies/mg. Lanes 15-20: PCR products from real-time PCR obtained on 5-fold serial dilutions of viral DNA from , $5 \times 10^{3}$ to 8 copies, lane 20: 2 copies, expected size $197 \mathrm{bp}$.

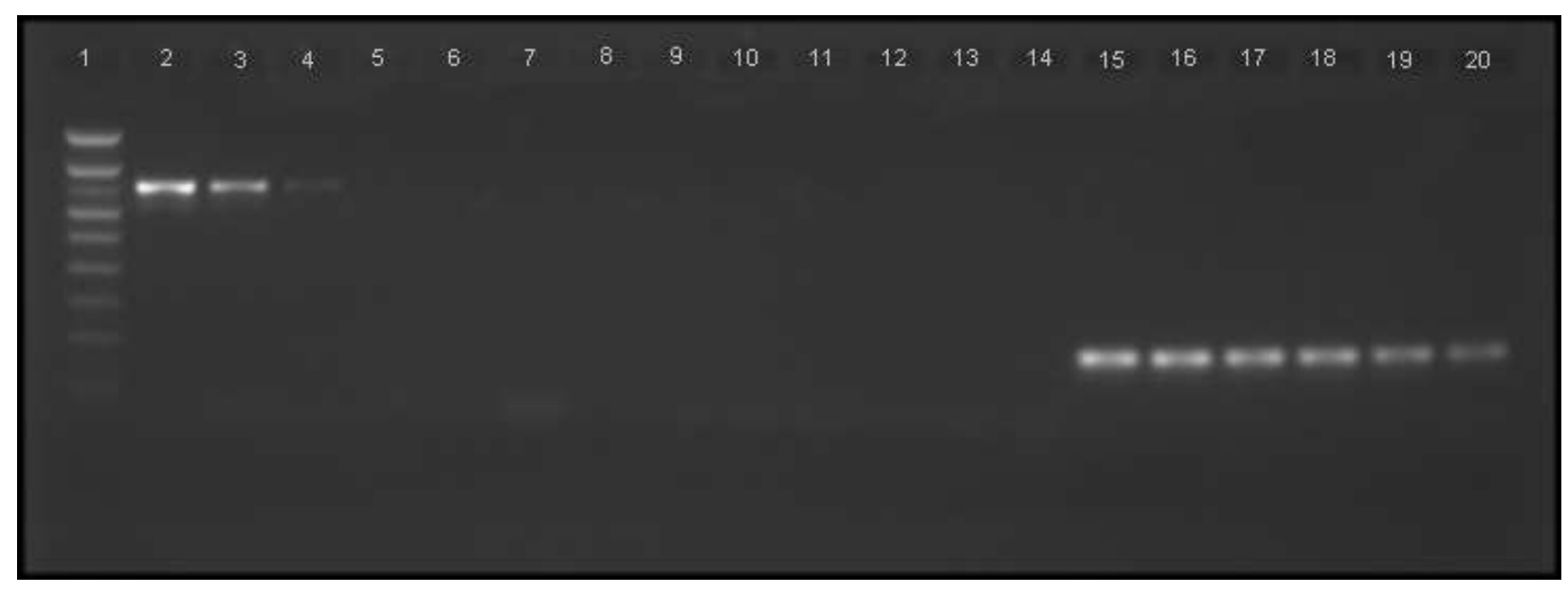

According to several standard curve assays, the dynamic range for the SYBR Green PCR has been estimated and it was possible to quantify sample OsHV-1 DNA copies number from at least 10 copies to $5.10^{6} / \mu \mathrm{L}$ (Fig. 3c). 
Fig. 3c. Dynamic range of SYBR Green PCR assay with standard curve for OsHV-1 DNA quantification, showing amplification plots for viral DNA dilutions ; A : $5 \times 10^{6}$ copies ; B : $2 \times 10^{5}$ copies ; C : $4 \times 10^{4}$ copies ; D : $8 \times 10^{3}$ copies ; E : $1 \times 10^{3}$ copies ; F : $2 \times 10^{2}$ copies ; G : $1 \times 10^{1}$ copies ; H : no template DNA, or negative control : NTC .

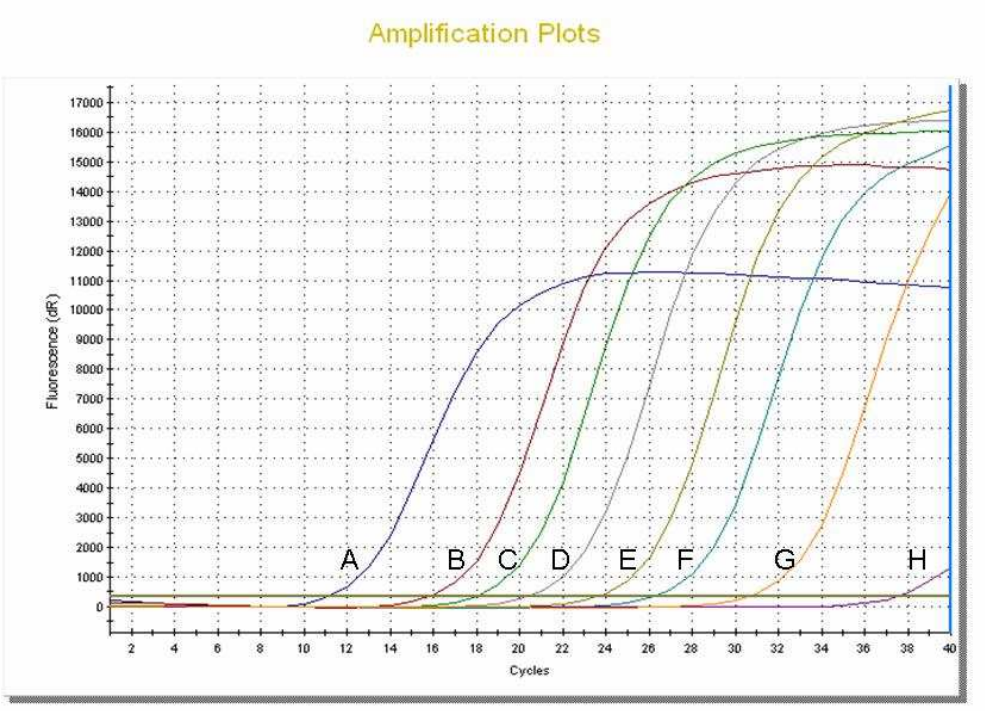

\section{2. 3 Assay precision}

Based on CT values and CV (coefficient of variation), the mean \pm S.D. intra-assay variability between the three serial dilution tests of OsHV-1 DNA (STD 1-3) was 1,6 \pm 0,4\% (Table 2). The inter-assay variability between six runs (Expt 1-6) with standard dilutions was $3,7 \pm 0,5 \%$ (Table 3 ). The means of $\mathrm{CV}$ values obtained are considered acceptable $(<5 \%)$ to validate the precision of the SYBR Green PCR assay. Moreover, the intra-assay reproductibility of triplicates was assessed for each OsHV-1 DNA dilution, the mean coefficient of variation calculated from triplicated CT values was $0,5 \pm 0,3 \%$. Within the inter-assay assessment, the coefficients of determination (Rsq), the slopes, and efficiency values were also recorded for each standard curve in order to precise accuracy 
and reproductibility. The mean values obtained were $0,999 \pm 0,01 \%$ for Rsq, $-3,31 \pm$ $0,07 \%$ for slopes, $100,5 \% \pm 2,72 \%$ for Efficiency data.

\section{Table 2}

Intra-assay variabilty calculated for viral genomic OsHV-1 DNA recorded with the SYBR Green real-time PCR from three serial dilution of OsHV-1 DNA (STD) .

\begin{tabular}{|c|c|c|c|c|c|c|c|}
\hline \multirow[b]{2}{*}{$\begin{array}{c}\text { Copy } \\
\text { number / } \mu \mathrm{L}\end{array}$} & \multicolumn{3}{|c|}{$\begin{array}{l}\text { Ct Avg. from triplicate values } \\
\text { of } 3 \text { intra-assay tests }\end{array}$} & \multirow[b]{2}{*}{ Mean value } & \multirow[b]{2}{*}{ S.D. } & \multirow[b]{2}{*}{ CV (\%) } & \multirow[t]{2}{*}{$\begin{array}{c}\text { Mean variability } \\
\pm \text { S.D. } \%\end{array}$} \\
\hline & STD1 & STD2 & STD 3 & & & & \\
\hline $1,00 \mathrm{E}+03$ & 24,72 & 23,97 & 24,39 & 24,36 & 0,307 & 1,3 & \\
\hline $2,00 \mathrm{E}+02$ & 26,83 & 26,48 & 27,46 & 26,92 & 0,405 & 1,5 & $1,6 \pm 0,4$ \\
\hline $4,00 \mathrm{E}+01$ & 29,42 & 30,61 & 29,13 & 29,72 & 0,640 & 2,2 & \\
\hline
\end{tabular}

\section{Table 3}

Inter-assay variabilty calculated for viral genomic OsHV-1 DNA recorded with the SYBR Green real-time PCR.

\begin{tabular}{ccccc}
\hline $\begin{array}{c}\text { Quantity } \\
\text { (copies } / \mu \mathrm{L})\end{array}$ & \multicolumn{2}{c}{ CT values (mean of 3 replicates by sam } \\
from 6 different days)
\end{tabular}




\section{2. 4 Oyster sample analysis}

During several mortality episodes in hatchery and nursery, oyster samples (larvae, spat, juveniles) were collected and frozen. On the basis of mortality rates and gross signs, an OsHV-1 infection was suspected for most of these samples (23). Twentyfive samples were analysed using both diagnostic tools, conventional PCR using $\mathrm{C}_{2} / \mathrm{C}_{6}$ primer pair and SYBR Green real-time PCR. Results are summarise in Table 4 (mean of triplicates for SYBR Green real-time PCR assays).

When no mortality was recorded during the rearing of samples presented in Table 4, the viral DNA copy number ranged between 0 copy (no CT value) and $1 \times 10^{3}$ copies per mg. In samples presenting abnormal mortalities the viral load ranged between $6 \times 10^{3}$ to $5.3 \times$ $10^{7}$ DNA copies per mg of tissue. Regarding sensitivity, less than 50 DNA copies/mg were mesured using SYBR Green real-time PCR from larvae (batch 9, 12, 14) and less than 500 DNA copies/mg in juvenile oyster (sample 22). Samples feld to be amplified by conventional $\mathrm{PCR}$ with $\mathrm{C}_{2} / \mathrm{C}_{6}$ primer set when the viral load was less than $7,8 \times 10^{3}$ (lanes 9-14, Fig. 3b). 
Table 4 Comparison of some field samples analysed using SYBR Green PCR and Conventional PCR

\section{M: mantle}

\begin{tabular}{|c|c|c|c|c|c|}
\hline $\begin{array}{l}\text { Batchs } \\
\text { or } \\
\text { samples } \\
\text { ref. }\end{array}$ & $\begin{array}{l}\text { Animal } \\
\text { size }\end{array}$ & $\begin{array}{c}\text { Tissue } \\
\text { analysed }\end{array}$ & $\begin{array}{l}\text { Abnormal } \\
\text { mortalities in } \\
\text { batchs }\end{array}$ & $\begin{array}{l}\text { SYBR Green PCR } \\
\text { results (viral DNA } \\
\text { copy number/mg) }\end{array}$ & $\begin{array}{c}\text { Conventional PCR } \\
\text { using } \mathrm{C}_{2} / \mathrm{C}_{6} \text { primer } \\
\text { pair }\end{array}$ \\
\hline 1 & $850 \mu \mathrm{m}$ & in toto & Yes & $6,28 \mathrm{E}+03$ & - \\
\hline 2 & $850 \mu \mathrm{m}$ & in toto & Yes & $7,86 \mathrm{E}+03$ & - \\
\hline 3 & $400 \mu \mathrm{m}$ & in toto & Yes & $2,10 \mathrm{E}+06$ & + \\
\hline 4 & $>200 \mu \mathrm{m}$ & in toto & Yes & $1,49 \mathrm{E}+06$ & + \\
\hline 5 & $>120 \mu \mathrm{m}$ & in toto & Yes & $8,81 \mathrm{E}+06$ & + \\
\hline 6 & $>140 \mu \mathrm{m}$ & in toto & Yes & $1,38 \mathrm{E}+07$ & + \\
\hline 7 & $400 \mu \mathrm{m}$ & in toto & Yes & $3,73 \mathrm{E}+05$ & + \\
\hline 8 & $1.5 \mathrm{~mm}$ & in toto & Yes & $1,7 \mathrm{E}+04$ & + \\
\hline 9 & $180 \mu \mathrm{m}$ & in toto & No & $4,51 \mathrm{E}+01$ & - \\
\hline 10 & $140 \mu \mathrm{m}$ & in toto & Yes & $2,62 \mathrm{E}+07$ & + \\
\hline 11 & $400 \mu \mathrm{m}$ & in toto & Yes & $1,75 E+05$ & + \\
\hline 12 & $>200 \mu \mathrm{m}$ & in toto & No & $4,10 \mathrm{E}+01$ & - \\
\hline 13 & $>140 \mu \mathrm{m}$ & in toto & Yes & $5,38 \mathrm{E}+07$ & + \\
\hline 14 & $40 \mu \mathrm{m}$ & in toto & No & $5,0 \mathrm{E}+01$ & - \\
\hline 15 & $40 \mu \mathrm{m}$ & in toto & No & 0: No CT & - \\
\hline 16 & $\leq 3 \mathrm{~cm}$ & M & No & 0: No CT & - \\
\hline 17 & $\leq 3 \mathrm{~cm}$ & M & No & $6,5 \mathrm{E}+02$ & - \\
\hline 18 & $\leq 3 \mathrm{~cm}$ & M & Yes & $2,31 \mathrm{E}+07$ & + \\
\hline 19 & $\leq 3 \mathrm{~cm}$ & M & Yes & $1,21 \mathrm{E}+07$ & + \\
\hline 20 & $\leq 3 \mathrm{~cm}$ & M & Yes & $3,1 \mathrm{E}+06$ & + \\
\hline 21 & $\leq 3 \mathrm{~cm}$ & M & No & $9,9 E+02$ & - \\
\hline 22 & $\leq 3 \mathrm{~cm}$ & M & No & $5,0 \mathrm{E}+02$ & - \\
\hline 23 & $\leq 3 \mathrm{~cm}$ & M & No & 0: No CT & - \\
\hline 24 & $\leq 3 \mathrm{~cm}$ & M & Yes & $6,3 \mathrm{E}+06$ & + \\
\hline 25 & $\leq 3 \mathrm{~cm}$ & M & Yes & $4,2 \mathrm{E}+06$ & + \\
\hline
\end{tabular}




\section{DISCUSSION}

The first description of a virus from a bivalve indicating membership of the Herpesviridaewas reported in adult Eastern oyters, C. virginica (Farley et al. 1972). In 1991, viruses interpreted as belonging to the Herpesviridae were associated with high mortality rates of hatchery-reared larval C. gigas in France (Nicolas et al. 1992) and in New Zealand (Hine et al. 1992). Since OsHV-1 has been isolated and charaterized, it is the sole recognized viral disease of Pacific oysters in Europe. So far, herpes-like viruses have been reported from nine different bivalve species around the world on the basis of transmission electron microscopy and molecular techniques. The number of host species seems to be still increasing. Arzul et al. (2001a, 2001b) have shown that OsHV-1 can infect several bivalve species.

Nevertheless, very few quantitative data are available for OsHV-1 in oysters. Even if sensitive PCR methods exist and are used routinely and a semi quantitative method was developped, the better of OsHV-1 infection needs not only qualitative data but also reliable quantitative information. No cell line from bivalves has been established. Thus, quantification of viruses infecting bivalves is quite impossible. We have developped a quantitative PCR method based on SYBR Green chemistry for OsHV-1 diagnostic.

OsHV-1 is the soly invertebrate herpesvirus which has been sequenced (GenBank accession no. AY509253). Moreover, OsHV-1 polymorphism has been reported, namely in region C ( Arzul et al. (2001b, 2001c), Friedman et al. 2005). In this context, it may be relevant to select primer pairs targeting a conserved region. Nevertheless, primer choice was based with the fact that $C_{9} / C_{10}$ primers targeted and amplified a sequence present in duplicate in genomic viral DNA. It was considered as an advantage in order to enhance sensitivity. However, during preliminary assays, the primer pair (Gp4/Gp7), targeting a sequence encoding for a putative glycoprotein was also used succesfully to amplify OsHV- 
1 DNA. It could be a primer set of interest since it targets a more conserved genomic region in OsHV-1 compared to area C ( Arzul et al. 2001).

SYBR Green real-time PCR specificity has been controled systematically by the melt curve data, verifying the presence of authentic amplicon as well as primer dimer or spurious product. Moreover, It was observed that samples that have been negative with SYBR Green real-time PCR (Table 4, samples 15, 16, 23, No CT) were also negative by conventionnal PCR with $\mathrm{C}_{2} / \mathrm{C}_{6}$ primer pair. For these samples no mortality was recorded during the rearing. In an other assay, one hundred samples have been also controled for both PCR methods and same concordance has been observed, all samples were negative (data not shown). These results show hability of SYBR Green real-time PCR to detect negative samples.

A competitive PCR assay has previously been developed (Arzul et al., 2002 ; Renault et al., 2004). Autors assign that the protocol allowed the detection of 45 DNA copies (1 fg) using genomic viral DNA as template, assuming a genome size around 207 $\mathrm{Kbp}$, and at least $1,3.10^{5}$ DNA copies (2.8 pg) per mg of oyster infected tissue. In our assay, using genomic viral DNA as template, at least 4 DNA copies $/ \mu$ L were detected. Regarding sample origin, preparation protocols and DNA extraction, real-time PCR allowed to detect in naturally infected material less than 50 viral DNA copies per mg. The assay precision data obtained confirm the accuracy and the reproductibility of the SYBR Green based real-time PCR.

This PCR quantitative method was successfully used to detect and quantify OsHV-1 DNA during productive infections in oyster larvae and spat. The assay has a large dynamic range (5 logs), so it could be usefull to analyze and quantify various OsHV-1 DNA copy amounts in samples. Detection of OsHV-1 in very early development stages has been carried out, comparing two protocols. Conventional PCR results with larval samples 
showed that the PCR using $\mathrm{C}_{2} / \mathrm{C}_{6}$ primer pair was less sensitive than the SYBR Green real-time PCR. However, the $\mathrm{C}_{2} / \mathrm{C}_{6}$ primer pair could allow the amplification of DNA from a variant of OsHV-1 while $\mathrm{C}_{9} / \mathrm{C}_{10}$ primer pair does not (Arzul et al., 2001c, Batista et al., 2006).

The SYBR Green real-time PCR assay performed on early larval samples showed that all samples assessed positive by conventional PCR, were also positve by the realtime PCR. These analysis data on early larval stages gave quantitative information on conventional PCR sensitivity. Comparing results obtained with the two PCR protocols using the same samples, the conventional PCR using $C_{2} / C_{6}$ primer pair allowed detect at least $1.7 \times 10^{4}$ viral DNA copies per mg. In spat presenting abnormal mortality rate, using conventional PCR with $\mathrm{C}_{2} / \mathrm{C}_{6}$ primer pair, Renault et al, (2004), detected $6,7 \times 10^{7}$ viral DNA copies per mg.

In addition, out of the 11 negative samples presented in table 4, two samples assessed negative by conventional PCR, both samples yielded weakly positive results using the real-time PCR confirming the higher sensitivity of the quantitative PCR with field samples. It could be assumed that quantitative data obtained from both (less than 50 viral DNA copy number per mg) did not represent an infected status associated with viral replication. Moreover, no abnormal mortality rates were recorded for both samples during period production. Such low viral loads have been reported in asymptomatic or healthy fish when cyprinid herpesvirus were detected, suggesting Herpesviridae typical latency ( Gilad et al., 2004, Goodwin et al., 2006).

According our findings, the SYBR Green real-time PCR developped here presents a ten fold better sensitivity with viral genomic DNA than conventional PCR, and an hundred fold better sensitivity with OsHV-1 infected oyster samples. Such differences in sensitivity 
between SYBR Green real-time PCR and conventional PCR have been already reported (Dhar et al., 2001, Abdul-Careem et al., 2006).

The increase of sensitivity in OsHV-1 diagnostic by quantitative PCR will help for better management of hatchery; namely to detect asymptomatic animals in prophylactic strategy screening. Nevertheless, a better knowledge is needed to define a thershold wich precises what viral amount could be associated to a disease status in oysters. Due to the very hight sensitivity of real-time PCR, special care should be take account during all the analysis process, in order to avoid contamination of reagents, material and samples and separate rooms shuld be used in each preparation step

Quantitative PCR provides both, qualitative and quantitative data. If, quality data have a large range of confidence according the hight specificity and extreme sensitivity of the real-time PCR developped, the quantitative data are more difficult to be dependable and repeatable. This is principaly due to the global variation in DNA concentrations within samples and variation related to the preservation time of the sample. The quantitation of genomic DNA could be reliable when isolation procedure is well determined, then viral DNA may lend itself for absolute quantitation against a standard curve.

In fact, the nature and the quality of samples, (preservation, preparation and nucleic acids extraction) are determinent to obtained reliable copy number ( Berrih-Aknin , 2000). We noticed such variations during this study. Notably, we observed that inhibition could occured when total DNA template in quantitative PCR exceeded $30 \mathrm{ng}$ per reaction (data not shown).

These variables should be well described and controled before to give sens to values of copy number. Interpretation of results may necessecite field backgroung of knowledges to associate a copy number with disease status of reared animals. 
In our work with herpes virus in molluscs, this point is specialy critical because we do not have other quantitative diagnostic tools to refere, such as cytopathic effects in cell culture and even any antibody quantifcation. One of the strategy being helpfull, could be to determine and fixe a whole protocole for each type of material, as a reference method. Absolute quantitation is possible if the isolation procedure and sample contents do not impact the PCR results (Berrih-Aknin, 2000). The detection threshold of our real-time SYBR Green PCR, should be still determined for the most relevant DNA extraction protocol with a large panel of samples.

In conclusion, the present quantitative PCR enabled the detection of high infection rates at different developemental stage of oysters. This technique, being rapid and applicable to a large number of samples, could enable diagnosis of OsHV-1 in less that two hours and appears to be valuable new tool for viral detection in oyster samples. Assessment of the severity of infection at different stages, in different oysters lines will be helpfull for the management of OsHV-1 disease in oyster culture. Moreover, with this PCR, viral load of each tissue may be assess on infected material in order to locate reservoir and replication area. Also, kinetic of viral amount during an outbreak may be monitored. This quantitative assay will help to discreminate latent to productive infection. In order to screen other herpesviruses in molluscs, new sets of primers could be considered to develop a multiplexe quantitative PCR. Nevertheless, futher work should be done in order to assess the lower limit of viral DNA detection in infected material, associated with an optimized DNA extraction protocol. Specific assays should be carried out with virus experimental enriched material with known initial number of copy compared to the recovered copy number evaluated by SYBR Green PCR. Finally a validation step should be done to define precisely the limits of use of this new diagnostic tool . 
Acknowledgements

We wish to express our gratitude to $\mathrm{Dr}$ Andrew Davison for critically reading the manuscript. We also are grateful to Dr Magnino from Stratagene for technical assistance. Pepin J.F. is extremely thankful to Dr. Comps M. for the voice of experience in molluscs pathology. This study would not have been possible without the financial contribution of the Region Poitou-Charentes.

\section{References}

Abdul-Careem, M.F., Hunter, B., Nagy, E., Read, L., Sanei, B., Spencer, L., Sharif, S., 2006. Development of a real-time PCR assay using SYBR Green chemistry for monitoring Marek's disease virus genome load in feather tips. J. Virol. Method. 133, 3440.

Arzul, I., 2001. Herpèsvirus infectant les bivalves marins: détection, génome et transmission. Thèse de doctorat. Université de Montpellier II, pp. 297.

Arzul, I. and Renault, T., 2002. Herpèsvirus et bivalves marins. Virologie, 6, 169-174.

Arzul, I., Renault, T. and Lipart, C., 2001b. Experimental herpes-like viral infections in marine bivalves: demonstration of interspecies transmission. Dis. aquat. Org. 46, 1-6.

Arzul, I., Nicolas, J.L., Davison, A.J. and Renault, T., 2001a. French scallops: a new host for ostreid herpesvirus 1. Virol. 290 (2), 342-349.

Arzul, I., Renault, T., Lipart, C. and Davison, A.J., 2001c. Evidence for interspecies transmission of oyster herpesvirus in marine bivalves. J. Gen. Virol. 82, 865-870.

Arzul, I., Renault, T., Thébault, A. and Gerard, A., 2002. Detection of oyster herpesvirus DNA and proteins in asymptomatic Crassostrea gigas adults. Virus Res. 84 (1-2), 151160. 
Barbosa-Solomieu, V., Dégremont, L., Vazquez-Juarez, R., Ascencio-Valle, F., Boudry, P., Renault, T., 2005. Ostreid herpesvirus 1 detection among three successive generations of Pacific oysters (Crassostrea gigas). Virus Res. 107, 47-56.

Barbosa-Solomieu, V., Miossec, L., Vazquez-Juarez, R., Ascencio-Valle, F., Renault, T., 2004. Diagnosis of Ostreid herpesvirus 1 in fixed paraffin-embedded archival samples using PCR and in situ hybridisation. J. Virol. Method. 119, 65-72.

Batista, F.M., Arzul, I., Pépin, J.F., Ruano, F., Friedman, C.S, Boudry, P., Renault, T., 2006. Detection of ostreid herpesvirus DNA by PCR in bivalve molluscs: A critical review. J. Virol. Method (In press).

Berrih-Aknin S., 2000. PCR quantitative, Ed. INSERM, Paris, pp. 93.

Davison, A. J., Trus, B. L., Cheng N., Steven A. C., Watson, M. S., Cunningham, C., Le Deuff, R.M., Renault, T.,2005. A novel class of herpesvirus with bivalve hosts. J. Gen. Virol. 86, 41-53.

Dhar, A.K., Roux, M.M., Klimpel, K.R., 2001. Detection and quantification of infectious hypodermal and hematopoietic necrosis virus and white spot virus in shrimp using real-time quantitaive PCR and SYBR Green chemistry. J. Clin. Microbiol. 39, 29352845.

Farley, C.A., Banfield, W.G., Kasnic, J.R.G., Foster, W.S., 1972. Oyster herpes-type virus. Science 178, 759-760.

Friedman, C.S., Estes, R.M., Stokes, N.A., Burge, C.A., Hargove, J.S., Barber, B.J., Elston, R.A., Burreson, E.M., Reece, K.S., 2005. Herpes virus in juvenile Pacific oysters Crassostrea gigas from Tomales Bay, California, coincides with summer mortality episodes. Dis. Aquat. Org. 63, 33-41

Gilad O., Yun S., Zagmutt-Vergara F.J., Leutenegger C.M., Bercovier H, Hedrick R.P., 2004. Concentrations of a koi herpesvirus (KHV) in tissues of experimentally infected Cyprinus carpio koi as assessed by real-time TaqMan PCR. Dis Aquat Org 60:179-187.

Goodwin A.E., Merry G.E., Sadler J., 2006. Detection of the herpesviral hematopoietic necrosis disease agent (Cyprinid herpesvirus 2) in moribund and healthy goldfish: validation of a quantitative PCR diagnostic method. Dis Aquat Org 69:137-143.

Hine, P.M. and Thorne, E.T., 1997. Replication of herpes-like viruses in haemocytes of adult flat oysters Ostrea angasi (Sowerby, 1871): an ultrastructural study. Dis. aquat. Org. 29, 189-196. 
Hine, P.M., Wesney, B. and Besant, P., 1998. Replication of a herpes-like virus in larvae of the flat oyster Tiostrea chilensis at ambient temperatures. Dis. aquat. Org. 32, 161171.

Hine, P.M., Wesney, B. and Hay, B.E., 1992. Herpesviruses associated with mortalities among hatchery-reared Pacific oysters, Crassostrea gigas. Dis. aquat. Org. 25, 143149.

Le Deuff, R.M., 1995. Contribution à l'étude de virus de mollusques marins apparentés aux Iridoviridae et aux Herpesviridae. Thèse de doctorat. Université de Bordeaux II, pp. 234.

Le Deuff, R.M and Renault T., 1999. Purification and partial genome characterization of a herpes-like virus infecting the Japanese oyster, Crassostrea gigas. J. Gen. Virol. 80,1317-1322.

Lipart, C. and Renault, T., 2002. Herpes-like virus detection in infected Crassostrea gigas spat using DIG-labelled probes. J. Virol. Methods, 101 (1-2),1-10.

Minson, A. C., Davison, A., Eberle, R., Desrosiers, R. C., Fleckenstein, B., McGeoch, D. J., Pellett, P. E., Roizman, B. \& Studdert, M. J. (2000). Family Herpesviridae. In Virus Taxonomy. Seventh Report of the International Committee on Taxonomy of Viruses, pp. 203-225. Edited by M. H. V. van Regenmortel, C. M. Fauquet, D. H. L. Bishop, E. B. Carstens, M. K. Estes, S. M. Lemon, J. Maniloff, M. A. Mayo, D. J. McGeoch, C. R. Pringle \& R. B. Wickner. San Diego: Academic Press

Nicolas, J.L., Comps, M. and Cochennec, N., 1992. Herpes-like virus infecting Pacific oyster larvae, Crassostrea gigas. Bull. Eur. Ass. Fish Pathol. 12 (1),11-13.

Renault T, Arzul I, Lipart C., 2004. Developement and use of an internal standard for oyster herpesvirus detection by PCR. J Virol Methods 121:17-23

Renault, T., 1998. Infections herpétiques chez les invertébrés: détection de virus de type herpès chez les mollusques bivalves marins. Virol. 2 (5), 401-403.

Renault, T. and Novoa, B., 2004. Viruses infecting bivalve molluscs. Aquat. Living Resour. 17, 397-409.

Renault, T., Le Deuff, R-M., Lipart, C. \& Delsert, C., 2000b. Development of a PCR procedure for the detection of a herpes-like virus infecting oysters in France. $J$ Virol Methods 88, 41-50.

Renault, T. and Arzul, I., 2001. Herpes-like virus infections in hatchery-reared bivalve larvae in Europe: specific viral DNA detection by PCR. J. Fish Dis. 24,161-167. 
Renault, T. and Lipart, C., 1998. Diagnosis of herpes-like virus infections in oysters using molecular techniques. European Aquaculture Society. Special Publication, 26, 235236.

Renault, T., Lipart, C. and Arzul, I., 2001. A herpes-like virus infects a non-ostreid bivalve species : virus replication in Ruditapes philippinarum larvae. Dis. Aquat. Org. 45, 1-7.

Renault, T., Cochennec, N., Le Deuff, R.M. and Chollet, B., 1994b. Herpes-like virus infecting Japanese oyster (Crassostrea gigas) spat. Bull. Eur. Assoc. Fish Pathol. 14 (2), 64-66.

Renault, T., Le Deuff, R.M, Cochennec, N., and Maffart, P., 1994a. Herpesviruses associated with mortalities among Pacific oyster, Crassostrea gigas, in France. Comparative study. Revue Médicale Vétérinaire, 145 (10), 735-742

Renault, T., Le Deuff, R.M., Chollet, B., Cochennec, N. and Gérard A., 2000a. Concomitant herpes-like virus infections among hatchery-reared larvae and nurserycultured spat Crassostrea gigas and Ostrea edulis. Dis aquat. Org. 42, 173-183.

Renault, T., Le Deuff, R.M., Cochennec, N., Chollet, B and Maffart, P., 1995. Herpes-like viruses associated with high mortality levels in larvae and spat of Pacific oysters, Crassostrea gigas: a comparative study, the thermal effects on virus detection in hatchery-reared larvae, reproduction of the disease in axenic larvae. Vet. Res. 26, 539-543.

Robledo, J. A. F., W. T. Pecher \& G. R. Vasta. 2000. High-throughput isolation of oyster DNA facilitates diagnosis of "Dermo" disease. Qiagen News 5:15-17 